\title{
Eksplorasi Kemampuan Siswa Dalam Memecahkan Masalah Matematika Pada Materi Program Linier
}

\author{
Ita Chairun Nissa ${ }^{1}$, Baiq Rika Ayu Febrilia ${ }^{2}$, Fitri Astutik ${ }^{3}$ \\ ${ }^{1,2}$ Program Studi Pendidikan Matematika, Universitas Pendidikan Mandalika \\ ${ }^{3}$ Program Studi Pendidikan Teknologi Informasi, Universitas Pendidikan Mandalika \\ Penulis Korespondensi: itachairunnissa@undikma.ac.id
}

\begin{abstract}
Linear programming is a method of determining the optimum value (maximum or minimum). Linear programming problems are generally presented in the form of story problems involving linear inequalities and straight-line graphs, each of which requires different strategies and knowledge. The study was conducted to measure the differences in the ability of students to solve linear programming problems in the context of story and graphic problems. The research method used is mixed methods with sequential explanatory design. This study used $2611^{\text {th }}$ grade high school students as test and interview respondents. Data analysis with comparative statistical test of two parties resulted in $t_{\text {statistics }}=3.63>t_{\text {one-party critical }}=$ 2.05 at $\alpha=0.05$, which means Ho is rejected. Based on these statistics, there is a significant difference in the ability of students to solve linear programming problems in the form of story questions and in the form of graphs. This study suggests the importance of providing students with a consistent, continuous and varied problem-solving experience in their level of difficulty.
\end{abstract}

Keywords: Students Ability Exploration, Problem Solving, Mathematical Problem, Linear Programming.

\begin{abstract}
Abstrak: Program linier memiliki muatan materi yang menekankan pada metode penentuan nilai optimum (maksimum atau minimum). Masalah program linier pada umumnya disajikan dalam bentuk soal cerita yang melibatkan pertidaksamaan linier dan grafik garis lurus yang masing-masing memerlukan strategi dan pengetahuan yang berbeda. Penelitian dilakukan untuk mengukur perbedaan kemampuan siswa yang memecahkan masalah program linier pada konteks soal cerita dan grafik. Metode penelitian yang digunakan adalah mixed methods dengan desain eksplanatoris sekuensial. Penelitian ini menggunakan 26 orang siswa kelas 11 SMA sebagai responden tes dan wawancara. Analisa data dengan uji statistik komparatif dua pihak menghasilkan $\mathrm{t}_{\text {statistik }}=3,63>\mathrm{t}_{\text {kritis }}$ satu pihak $=2,05$ pada $\alpha=0,05$ yang artinya Ho ditolak. Dengan Berdasarkan statistik tersebut maka ada perbedaan yang signifikan atas kemampuan siswa yang memecahkan masalah program linier dalam bentuk soal cerita dan dalam bentuk grafik. Penelitian ini menyarankan pentingnya memberikan pengalaman pemecahan masalah kepada siswa secara konsisten, berkelanjutan dan beragam dalam tingkat kesukarannya.
\end{abstract}

Kata kunci: Eksplorasi Kemampuan Siswa, Pemecahan Masalah, Masalah Matematika, Program Linier.

\section{PENDAHULUAN}

Matematika memainkan peranan yang cukup penting dalam perkembangan proses berpikir manusia yang strategis dan juga sistematis yang dipergunakan untuk menganalisia dan memecahkan suatu masalah. Kemampuan ini membantu seseorang untuk dapat mengantisipasi, merencanakan, memutuskan, dan memecahkan masalah sehari-hari dengan tepat. Mengingat pentingnya kemampuan pemecahan masalah tersebut maka kemampuan ini pun diajarkan di tingkat sekolah. Pada mata pelajaran matematika, kemampuan ini seringkali diajarkan melalui soal cerita. Untuk dapat memecahkan masalah matematika berbentuk soal cerita maka siswa terlebih dahulu harus mampu memahami maksud narasi cerita dalam masalah, mampu memodelkan 
objek masalah ke dalam simbol matematika sampai, mampu menyelesaikan dengan strategi yang tepat dan menemukan solusinya (Hanifah, 2011). Namun kenyataan yang seringkali terjadi adalah siswa masih mengalami kesulitan menyelesaikan masalah matematika yang berbentuk soal cerita daripada masalah matematika yang berbentuk soal hitungan semata (Nurohmah \& Setianingsih, 2014). Kesalahan siswa dalam menyelesaikan soal cerita pada umumnya terletak pada kesalahan dalam memahami bahasa yang menyebabkan siswa kesulitan mengidentifikasi data yang diketahui (Ningrum, 2013).

Program linier merupakan salah satu materi matematika wajib di tingkat SMA. Materi ini berkaitan dengan masalah optimalisasi suatu fungsi linier (minimum dan maksimum) yang disebabkan oleh adanya kendala atau pembatasan pada persamaan atau pertidaksamaan linier tersebut. Masalah-masalah matematika terkait program linier cukup diminati karena konsep program linier dapat digunakan untuk membuat model matematika dari suatu masalah yang besar dan rumit serta dapat memecahkan masalah tersebut dengan algoritma yang efektif dan waktu yang rasional (Bazaraa et al., 2011). Program linier merepresentasikan banyak hal terkait dengan permasalahan rutin yang sering ditemui dalam kehidupan sehari-hari (Vanderbei, 2015). Beberapa penelitian terkait kemampuan siswa untuk memecahkan masalah program linier telah dilakukan. Hasil penelitian pemecahan masalah pada siswa sekolah menengah menunjukkan bahwa siswa masih memiliki kemampuan yang kurang baik dalam menyelesaikan masalah program linier yang berbentuk soal cerita (Asih, 2011). Kesalahan siswa disebabkan oleh kesalahan dalam menginterpretasi bahasa, kesalahan dalam menerapkan prosedur, dan kesalahan teknis dalam perhitungan matematika. Beberapa siswa masih tergolong rendah dalam hal memahami masalah sehingga siswa mengalami kesulitan dalam menyusun rencana untuk menentukan solusi. Selain itu siswa juga masih mengalami kesalahan dalam mengubah kalimat verbal menjadi model matematika (Ninik et al., 2014). Kelemahan siswa juga nampak pada aspek memahami masalah dan mentransfer informasi menjadi variabel, kesalahan dalam melakukan prosedur matematika dan kesalahan dalam penarikan kesimpulan (Mustaqim, 2013).

Berbagai penelitian yang telah dilakukan sebelumnya, menitikberatkan bahwa tahapan memahami masalah menjadi kunci penting keberhasilan siswa dalam memecahkan masalah matematika program linier. Kesalahan siswa pada tahap memahami masalah sangat mempengaruhi keberhasilan siswa dalam merencanakan strategi. Namun perlu diketahui bahwa beberapa penelitian sebelumnya menggunakan masalah matematika program linier dalam bentuk soal cerita saja. Masih sedikit penelitian mengenai pemecahan masalah matematika program linier yang menggunakan masalah dalam bentuk grafik. Kedua bentuk masalah ini secara tidak langsung dapat mempengaruhi keberhasilan siswa dalam memecahkan masalah program linier sehingga kasus ini perlu menjadi perhatian bagi guru karena kemampuan siswa sangatlah beragam. Berdasarkan asumsi bahwa proses memecahkan masalah matematika program linier dalam bentuk cerita dan grafik memerlukan strategi yang berbeda, maka kami mengajukan hipotesis penelitian yaitu ada perbedaan kemampuan 
siswa yang memecahkan masalah program linier dalam bentuk cerita dan grafik. Selain menjawab hipotesis tersebut, penelitian ini juga akan menjelaskan perbedaan strategi siswa dalam menjawab kedua bentuk masalah matematika tersebut.

\section{METODE}

Subjek penelitian ini adalah 26 orang siswa kelas 11 SMA Islam Al-Azhar NW Kayangan Lombok Barat. Subjek penelitian tersebut dipilih menggunakan teknik purposive sampling dimana siswa dipilih berdasarkan variasi kemampuan matematika dan komunikasinya yang baik. Metode penelitian yang digunakan adalah mixed methods karena proses penelitian ini melibatkan data kuantitatif dan kualitatif baik dalam hal pengumpulan data, analisa data dan pengintegrasian data. Metode mixed methods dalam penelitian ini menggunakan desain eksplanatoris sekuensial melalui dua fase yaitu fase kuantitatif dan fase kualitatif. Fase kualitatif dibangun berdasarkan data kuantitatif yang berfungsi untuk mendeskripsikan data yang telah diperoleh pada fase kuantitatif. Data kuantitatif dalam penelitian ini adalah hasil tes sedangkan data kualitatifnya adalah hasil wawancara. Strategi siswa dalam memecahkan masalah program linier merujuk pada strategi pemecahan masalah heuristik (Schoenfeld, 2014) sedangkan kinerja siswa saat melakukan pemecahan masalah tersebut dinilai menggunakan suatu rubrik holistik (Rosli et al., 2013). Rubrik holistik ini menilai kinerja pemecahan masalah secara kuantitatif dalam bentuk skor pada tahap memahami masalah, tahap menyusun rencana, dan tahap menjalankan rencana. Sedangkan tahap keempat yaitu melihat kembali cenderung untuk dinilai secara kualitatif. Rubrik holistik untuk menilai kinerja pemecahan masalah siswa ditunjukkan pada Tabel 1.

Tabel 1. Kriteria Validitas Instrumen

\begin{tabular}{|c|c|}
\hline Tahapan & Kriteria Penilaian dan skor \\
\hline \multirow{3}{*}{$\begin{array}{l}\text { Memahami } \\
\text { masalah }\end{array}$} & Siswa benar-benar dapat memahami masalah secara lengkap (skor 2) \\
\hline & Siswa menafsirkan dengan benar hanya pada sebagian masalah saja (skor 1) \\
\hline & Siswa benar-benar salah memahami masalah secara keseluruhan (skor 0) \\
\hline \multirow{3}{*}{$\begin{array}{l}\text { Menyusun } \\
\text { rencana }\end{array}$} & Siswa menerapkan rencana dengan tepat dan menghasilkan solusi benar (skor 2) \\
\hline & $\begin{array}{l}\text { Siswa menerapkan rencana dengan tepat dari sebagian masalah yang ditafsirkan } \\
\text { dengan benar (skor 1) }\end{array}$ \\
\hline & Siswa tidak memiliki rencana atau memiliki rencana tetapi tidak tepat (skor 0) \\
\hline \multirow{3}{*}{$\begin{array}{l}\text { Menjalankan } \\
\text { rencana }\end{array}$} & Siswa dapat melakukan komputasi dan memperoleh jawaban yang benar (skor 2) \\
\hline & $\begin{array}{l}\text { Siswa masih memiliki kesalahan komputasi secara parsial untuk masalah yang } \\
\text { banyak jawaban (skor 1) }\end{array}$ \\
\hline & Siswa tidak memiliki jawaban atau menghasilkan jawaban yang salah (skor 0) \\
\hline
\end{tabular}

Seluruh data yang telah dikumpulkan kemudian dianalisa secara kuantitatif dan kualitatif. Data kuantitatif dianalisa dengan statistik komparasi dua sampel dengan uji t. Uji t yang dilakukan bertujuan untuk menguji hipotesis dengan kriteria pengujian yaitu apabila $-\mathrm{t}_{\text {kritis satu pihak }} \leq \mathrm{t}_{\text {statistik }} \leq+\mathrm{t}_{\text {kritis }}$ satu pihak maka Ho diterima pada $\alpha=0.05$. Adanya perbedaan yang sigfinikan terhadap hasil tes siswa dapat diartikan bahwa ada perbedaan kemampuan siswa memecahkan masalah matematika program linier pada konteks soal cerita dan grafik. Sementara itu, data kualitatif dianalisa melalui tiga tahap yaitu reduksi data, penyajian data, dan penarikan kesimpulan. 


\section{HASIL DAN PEMBAHASAN}

Aktivitas utama yang mendasari penelitian ini yaitu merancang tes pemecahan masalah program linier. Tes program linier dalam penelitian terdiri empat soal dimana masing-masing dua soal berbentuk soal cerita dan dua soal lagi berbentuk soal grafik. Tes matematika program linier dalam bentuk soal cerita bersumber dari Buku Matematika SMA/MA/SMK/MAK Kelas 11 Kementerian Pendidikan dan Kebudayaan Tahun 2017. Soal tes program linier ke-1 dalam bentuk soal cerita menuntut siswa mampu memahami makna bobot nilai tes dan pengg unaan operasi matematika yang tepat. Ada informasi dalam soal yang tidak disebutkan secara eksplisit yaitu informasi nilai maksimal dari suatu nilai tes adalah 100, dimana siswa harus mampu menggali sendiri informasi ini melalui pengalamannya. Soal nomor 1 tes program linier dapat dilihat pada Gambar 1.

\section{Hartono mengikuti ujian akademi kepolisian pada tahun 2020. Sistem ujian yang selektif dan kompetitif mengharuskan setiap peserta ujian harus memiliki nilai gabungan tes tulis dan tes fisik minimal 65 dengan bobot 0.6 untuk tes tulis dan 0.4 untuk tes fisik dengan nilai minimal salah satu tes adalah 55. Berapa nilai tes tulis dan tes fisik yang harus diperoleh hartono agar dapat lulus ujian?"}

Gambar 1. Soal Nomor 1 Tes Matematika Program Linier

Soal nomor 2 tes matematika program linier berikutnya memuat masalah dimana informasi penting dalam soal diberikan dengan lebih sedikit bilangan. Hal ini bertujuan agar siswa mampu menggunakan pengalaman sehari-hari dalam mengidentifikasi data dan informasi yang penting dalam soal. Selain itu, terdapat informasi yang sebenarnya tidak diperlukan dalam proses perhitungan matematika yaitu lahan berbentuk persegi panjang. Siswa mungkin dapat berpikir bahwa mereka perlu menentukan ukuran panjang dan lebar dari lahan tersebut. Siswa yang memiliki intuisi yang baik akan memiliki wawasan bahwa masalah ini sebenarnya terkait dengan program linier, khususnya kemampuan untuk menyelesaikan pertidaksamaan linier yang dicirikan melalui kata kunci "lebih luas". Masalah ini memuat berbagai kemungkinan jawaban benar walaupun tidak dinyatakan secara eksplisit dalam soal. Siswa diminta menentukan luas lahan yang mungkin untuk ditanam jagung dan kentang berdasarkan situasi yang dialami petani. Siswa yang memiliki pemikiran kritis akan mencoba menentukan lebih dari satu jawaban, karena melalui kata kunci "mungkin" yang mengindikasikan ada jawaban lain yang juga menjadi solusi dari masalah tersebut. Soal nomor 2 tes matematika program linier disajikan pada Gambar 2.

Seorang petani di desa memiliki lahan berbentuk persegi panjang seluas $600 \mathrm{~m}^{2}$. Dia hendak menanam jagung dan kentang di lahan tersebut. Saat ini petani itu tidak memiliki cukup modal untuk menanami seluruh lahannya, tetapi dia ingin lahannya lebih luas ditanami kentang. Berapa luas lahan yang mungkin untuk ditanami jagung dan kentang?

Gambar 2. Soal Nomor 2 Tes Matematika Program Linier 
Soal nomor 3 tes matematika program linier disajikan dalam bentuk grafik. Tes ini membutuhkan kemampuan yang berbeda dibandingkan dengan tes dalam bentuk soal cerita. Siswa harus mampu menginterpretasikan grafik ke dalam bentuk persamaan garis lurus dengan menentukan dua titik potong garis terhadap sumbu koordinat $x$ dan $y$. Terdapat informasi dalam soal bahwa nilai maksimum diperoleh pada titik K, dimana informasi ini akan memunculkan berbagai macam penafsiran daerah penyelesaian. Soal nomor 3 tes matematika program linier disajikan pada Gambar 3.

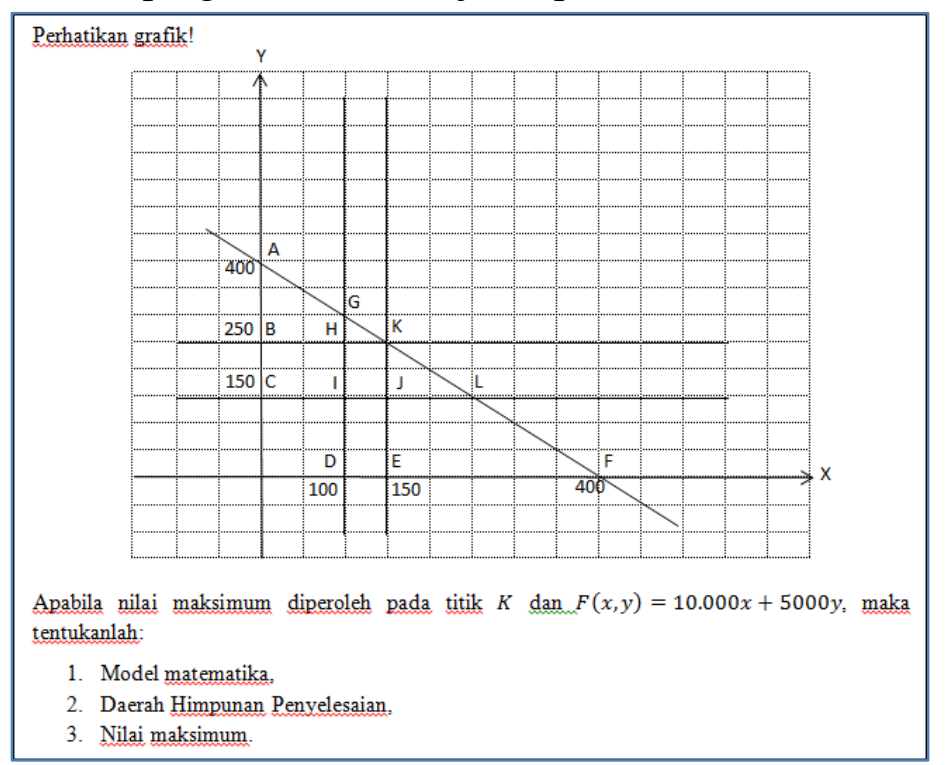

Gambar 3. Soal Nomor 3 Tes Matematika Program Linier

Soal tes matematika program linier yang terakhir yaitu soal nomor 4 memuat representasi grafik yang dirancang serupa seperti pada soal nomor 3 namun berbeda pada informasi yang diberikan dimana telah diberikan garis $x \leq 6$ dan garis $y \geq 4$. Soal nomor 4 tes matematika program linier disajikan pada Gambar 4

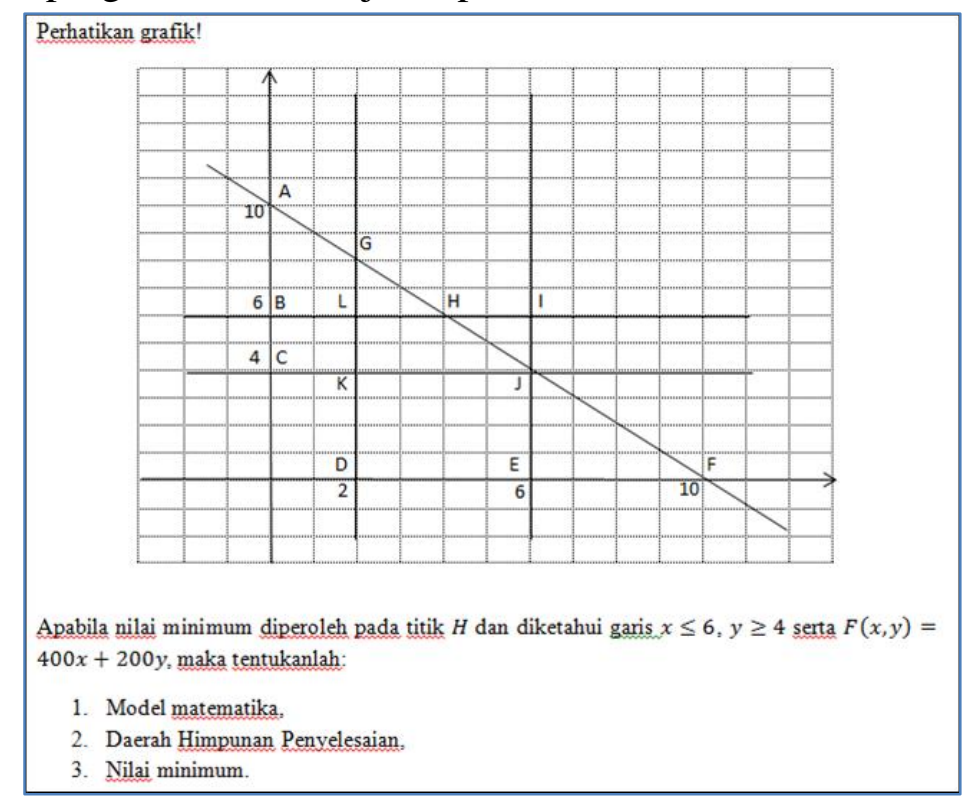

Gambar 4. Soal Nomor 4 Tes Matematika Program Linier 
Keempat masalah matematika yang diujikan kepada siswa baik dalam konteks soal cerita atau grafik ternyata mampu mendeskripsikan kinerja siswa yang beragam. Namun, ada kesamaan diantara keduanya yaitu sebagian besar siswa masih belum mampu berpikir kritis terhadap data penting dalam soal yang tidak disebutkan secara langsung. Siswa juga belum mampu menafsirkan bahwa masalah yang diberikan menghasilkan beberapa jawaban benar. Hasil tes siswa tersebut secara kuantitatif dianalisis secara statistik dengan menggunakan fitur data analysis tool pada Ms. Excel versi 2010. Analisa data statistik komparasi dua sampel melalui uji-t dua pihak pada $\alpha=0.05$ telah menghasilkan $t_{\text {statistik }}>$ $\mathrm{t}_{\text {kritis }}$ satu pihak, sehingga dalam hal ini Ho Ditolak. Sehingga dapat dikatakan ada perbedaan kemampuan siswa yang memecahkan masalah program linier dalam bentuk soal cerita dan dalam bentuk grafik. Tabel 2 menunjukkan ringkasan data uji-t.

Tabel 2. t-Test Paired Two Sample for Means

\begin{tabular}{lll}
\hline Ukuran Pemusatan Data & Hasil Tes Soal Grafik & Hasil Tes Soal Cerita \\
\hline Mean & 53,84615385 & 45,19230769 \\
Variance & 84,61538462 & 100,9615385 \\
Observations & 26 & 26 \\
Pearson Correlation & 0,208062595 & \\
Hypothesized Mean Difference & 0 & \\
Df & 25 & \\
$t$ Stat & 3,638034376 & \\
$P(T<=t)$ one-tail & 0,000623525 & \\
$t$ Critical one-tail & 1,708140761 & \\
\hline
\end{tabular}

Adanya perbedaan hasil tes siswa yang ditunjukkan melalui hasil uji statistik tersebut, menunjukkan hal yang serupa dengan deskripsi jawaban siswa. Beberapa gambaran kinerja siswa akan dijelaskan pada bagian ini. Pembahasan ini dimulai dari kesalahan siswa memecahkan soal nomor 1 tes matematika program linier pada konteks soal cerita. Siswa melakukan kekeliruan dalam merumuskan model matematika yang disebabkan kegagalan siswa untuk memahami konteks masalah dimana nilai paling tinggi dari suatu tes atau ujian adalah 100 dan akibatnya siswa hanya benar sebagian saja dalam menuliskan model matematika. Contoh pekerjaan siswa menyelesaikan masalah matematika program linier untuk soal nomor 1 disajikan pada Gambar 5.

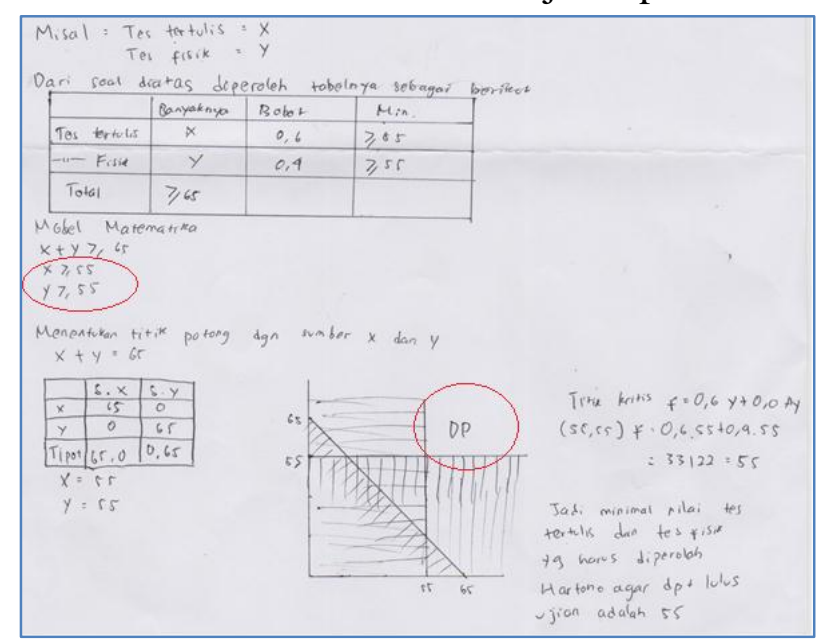

Gambar 5. Contoh Pekerjaan Siswa Soal Nomor 1 Tes Matematika Program Linier 
Kesalahan siswa dalam merumuskan model matematika mengakibatkan kesalahan dalam menentukan daerah penyelesaian, sehingga jawaban yang dituliskan masih belum sesuai dengan solusi yang diharapkan. Kesalahan siswa pada bagian disebabkan oleh kurangnya kemampuan siswa dalam mentransformasi dengan tepat bahasa soal ke dalam model matematika (Mahmudah \& Sutarni, 2017). Hasil wawancara menunjukkan siswa belum memiliki pengalaman dalam memecahkan masalah matematika seperti dalam tes. Selama ini pengalaman siswa hanya terbatas memecahkan masalah program linier dalam bentuk yang sederhana dimana informasi penting dinyatakan secara eksplisit dan solusi yang diharapkan merupakan jawaban tunggal. Jadi siswa belum terbiasa untuk mengkritisi suatu masalah. Petikan hasil wawancara dengan salah satu siswa terkait kasus di atas dapat dilihat pada Tabel 3.

Tabel 3. Petikan Transkip Wawancara

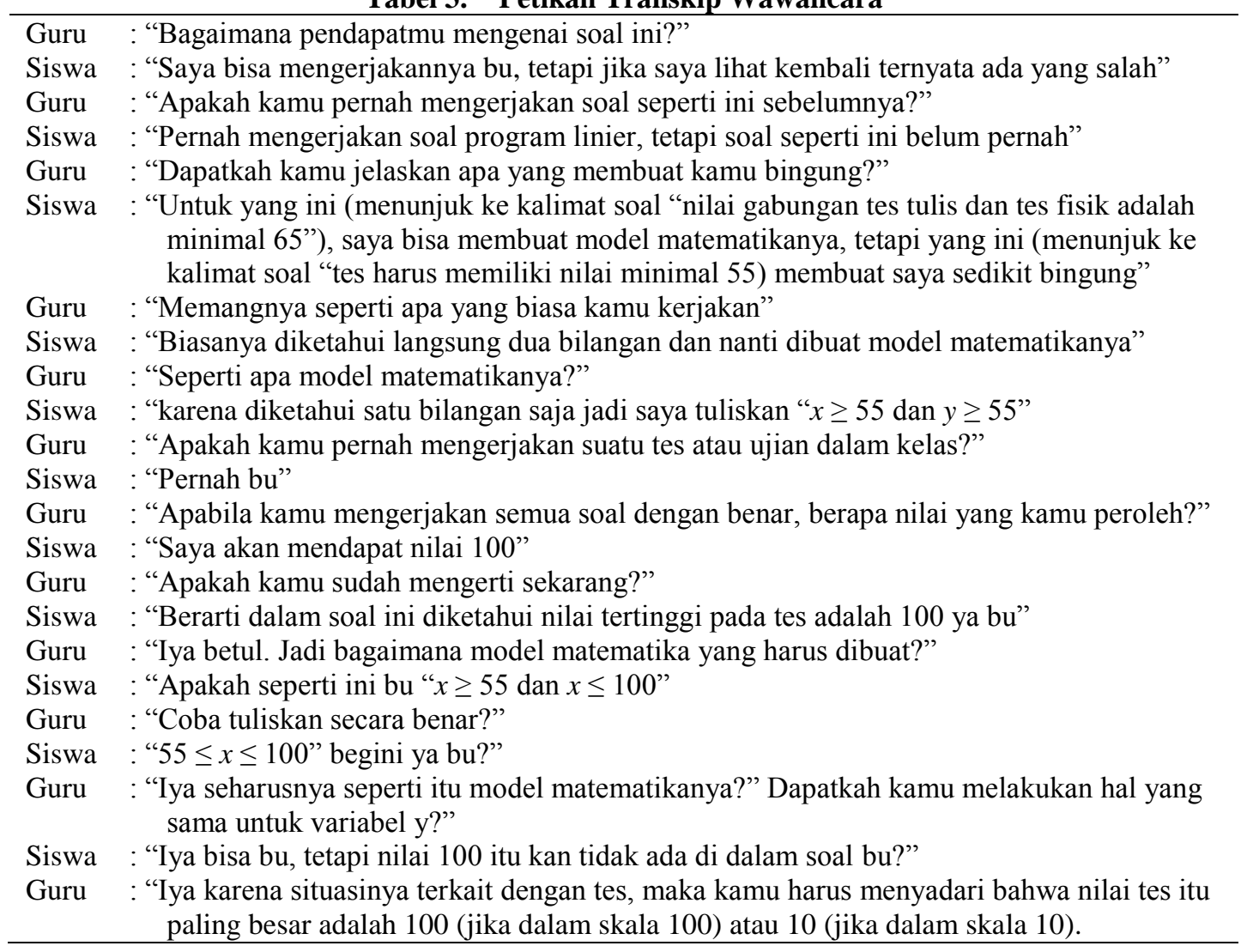

Pada soal nomor 2 siswa berhasil merumuskan model matematika dengan benar sesuai dengan konteks masalahnya, namun masih melakukan kesalahan dalam langkahlangkah menggambar garis $x-y=0$. Siswa hanya mampu menentukan satu saja titik potong garis $x-y=0$ terhadap sumbu- $x$ dan sumbu- $y$ yaitu (0.0). Seharusnya siswa perlu menentukan satu lagi titik potong agar dapat menggambar garis dengan tepat, namun siswa belum dapat melakukannya. Contoh pekerjaan siswa pada soal nomor 2 tes matematika program linier disajikan pada Gambar 6. 


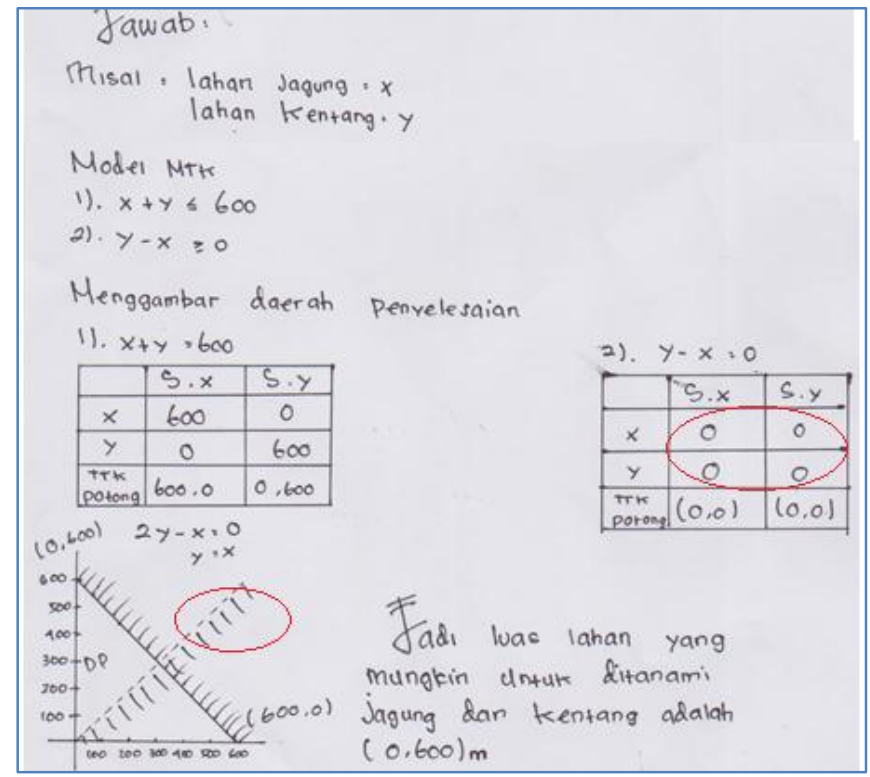

Gambar 6. Contoh Pekerjaan Siswa Soal Nomor 2 Tes Matematika Program Linier

Hasil wawancara dengan salah satu siswa diketahui bahwa pada mulanya siswa kesulitan untuk menggambar garis karena titik potong yang ia miliki hanya titik (0.0) saja. Kemudian karena garis $x+y=600$ berada di Kuadran I (posisi kanan atas), maka siswa mencoba menarik garis yang melalui titik (0.0) tersebut. Kesalahan siswa ini disebabkan karena siswa tidak dapat mengingat kembali prosedur menentukan persamaan garis lurus yang sebenarnya telah mereka pelajari saat di kelas 10. Materi persamaan garis lurus merupakan prasyarat untuk mempelajari program linier, sehingga sangat diperlukan sebagai landasan untuk menyelesaikan masalah program linier. Kemampuan siswa mengingat kembali materi yang telah dipelajarinya ternyata merupakan kesalahan yang cukup sering terjadi. Kesalahan ini terjadi disebabkan antara lain siswa kurang menguasai materi prasyarat yaitu pertidaksamaan linier, siswa kurang terampil menuliskan informasi yang diketahui dan variabel yang ditanyakan serta kurang pengalaman memecahkan masalah dalam variasi yang berbeda (Amaliah, 2018). Tabel 4 menunjukkan petikan hasil wawancara terkait kasus di atas.

Tabel 4. Petikan Transkip Wawancara

\footnotetext{
Guru : "Bagaimana kamu dapat menggambar garis $\mathrm{x}-\mathrm{y}=0$ ?"

Siswa : "Pertama-tama saya mencari titik potong terhadap sumbu x dan sumbu y di titik (0.0)"

Guru : "Dapatkah kamu menunjukkan titik (0.0) pada Bidang Kartesius ?"

Siswa : "Iya disini (menunjuk pada titik pusat Bidang Kartesius)"

Guru : "Adakah titik potong yang lain?"

Siswa : "Ada. Titik (0.0) juga (sambil menunjuk jawabannya pada tabel)"

Guru : "Titik itu kan titik yang sama dengan sebelumnya"

Siswa : "Iya"

Guru : "Jadi bagaimana caramu bisa menggambar garis $\mathrm{x}-\mathrm{y}=0$ pada Bidang Kartesius seperti ini (menunjuk gambar yang dibuat siswa pada lembar jawabannya)"

Siswa : "Awalnya saya bingung bu, karena titiknya hanya (0.0) saja. Terus saya lihat garis yang satunya (garis $x+y=600$ ) berada di sebelah sini (menunjuk kuadran I), maka saya buat saja garisnya yang mengarah ke daerah ini (menunjuk kuadran I)"

Guru : "Apakah kamu sebelumnya pernah mengerjakan soal membuat garis yang telah diketahui persamaannya?"
} 


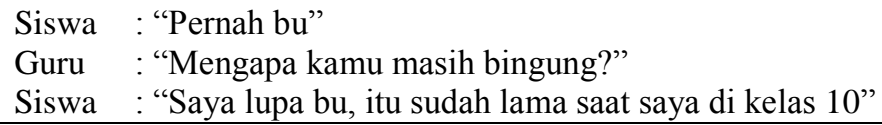

Hasil tes dan wawancara dengan siswa memberikan informasi bahwa siswa masih mengalami kesulitan pada tahap memahami masalah dan belum dapat memberikan berbagai kemungkinan jawaban benar seperti yang diharapkan dalam soal. Secara umum, kesalahan tersebut disebabkan minimnya pengalaman siswa dalam memecahkan berbagai masalah program linier sehingga siswa belum mampu berpikir kritis terhadap apa yang ia hadapi. Kesalahan siswa pada tahap ini kemudian berdampak pada tahapan pemecahan masalah selanjutnya. Dengan demikian, tahap memahami masalah dapat dikatakan sebagai suatu titik kritis dari kemajuan kinerja siswa yang sangat menentukan apakah ia akan sukses pada tahap pemecahan masalah selanjutnya. Keberhasilan siswa membuat model matematika akan menjadi dukungan terbaik dalam menyusun rencana dan melaksanakannya secara benar. Namun hasil berbeda ditunjukkan pada hasil tes siswa yang memecahkan masalah program linier dalam bentuk grafik dimana hasilnya lebih baik dibandingkan dengan tes dalam konteks soal cerita. Sebagian besar langkah siswa dalam menjawab soal sudah benar. Jawaban siswa pada tes ini nampak lebih beragam dengan munculnya beberapa kemungkinan daerah penyelesaian yang memenuhi. Jadi secara umum sebagian besar siswa mampu menjawab tes yang diberikan walaupun masih ada kesalahan kecil dalam melakukan perhitungan matematika. Contoh pekerjaan siswa pada soal nomor 3 tes matematika program linier disajikan pada Gambar 7.

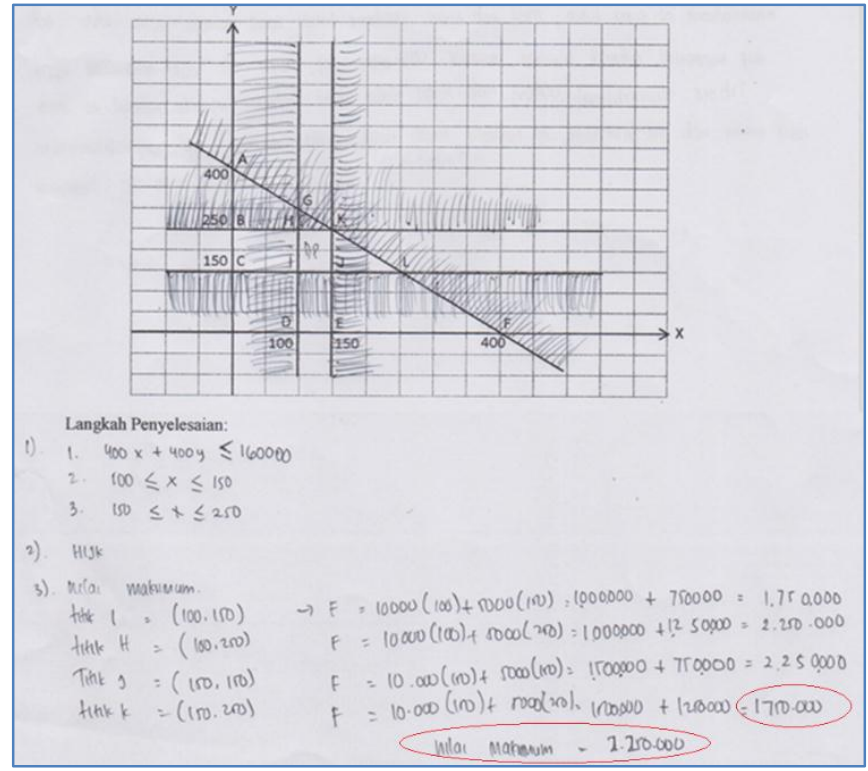

Gambar 7. Contoh Pekerjaan Siswa Soal Nomor 3 Tes Matematika Program Linier

Pada Gambar 7, nampak siswa mampu membuat model matematika secara benar sedemikian sehingga memenuhi persyaratan bahwa nilai maksimum berada pada titik K. model matematika yang benar ini kemudian mengarahkan siswa kepada penentuan daerah penyelesaian yang juga benar. Namun, pada saat siswa ingin menentukan nilai maksimum dari daerah penyelesaian tersebut siswa melakukan sedikit kesalahan perhitungan 
matematika. Dalam proses memecahkan masalah matematika siswa terkadang melakukan kecerobohan dalam menentukan rumus dan melakukan operasi hitung matematika (Rahmawati \& Permata, 2018). Kemampuan siswa memecahkan soal nomor 3 seharusnya dapat menjadi pengalaman untuk memecahkan soal nomor 4 namun ternyata terdapat lebih banyak kesalahan muncul. Contoh pekerjaan siswa pada soal nomor 4 tes matematika program linier disajikan pada Gambar 8.

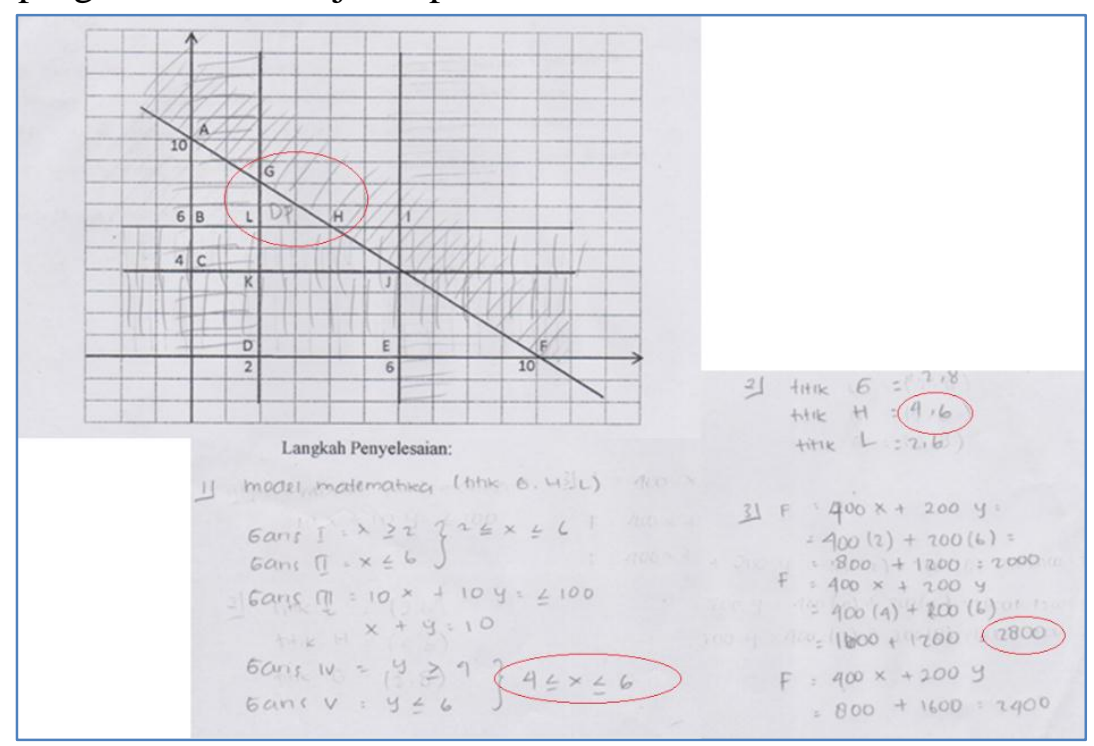

Gambar 8. Judul Gambar

Gambar 8 menunjukkan bahwa siswa tidak memperhatikan persyaratan yang telah diberikan dalam soal bahwa nilai minimum diperoleh pada titik H. Seharusnya siswa dapat melihat kembali jawabannya dan menemukan kontradiksi antara apa yang diketahui dengan jawaban yang diperoleh. Pada kasus ini sebenarnya telah diketahui bahwa nilai minimum diperoleh pada titik $\mathrm{H}$, tetapi hal ini tidak sesuai dengan hasil perhitungan yang menunjukkan nilai fungsi pada titik $\mathrm{H}$ adalah paling besar dibandingkan dengan titik $\mathrm{G}$ dan titik L. Hasil wawancara dengan siswa diperoleh informasi bahwa siswa tidak memperhatikan dengan seksama kalimat soal. Siswa beranggapan bahwa yang harus ditentukan adalah nilai maksimum sama seperti pada soal nomor 3 sebelumnya. Kesalahan siswa dalam memecahkan masalah program linier adalah kesalahan prinsip dalam menentukan nilai minimum yang disebabkan oleh kesalahan memahami fakta atau istilah yang dinyatakan secara eksplisit (Mubarokah \& Nusantara, 2020), bahkan masalah matematika program linier yang bersumber dari buku paket pun masih dirasakan sulit untuk dipecahkan oleh siswa (Nissa \& Lestari, 2015).

Perbedaan kemampuan siswa untuk memecahkan masalah program linier dalam bentuk soal cerita dan grafik yang telah diuraikan dalam penelitian ini memberikan gambaran kepada kita bahwa konteks masalah matematika yang diberikan kepada siswa dapat mempengaruhi cara berpikir mereka. Soal cerita menuntut siswa untuk mampu memahami masalah sesuai konteksnya yang kemudian dirumuskan dalam model matematika. Prinsip ini menjadi tantangan bagi siswa yang minim pengalaman pemecahan masalah sehingga beberapa kesalahan terjadi secara konseptual. Begitu pula 
soal matematika dalam bentuk grafik yang juga menantang representasi visual siswa. Siswa harus mampu menginterpretasikan grafik dengan tepat sehingga dapat diketahui maknanya. Pada akhirnya, kedua bentuk soal matematika tersebut sangat diperlukan oleh praktek pembelajaran matematika untuk meningkatkan variasi pengalaman memecahkan masalah matematika. Semakin kaya pengalaman siswa untuk memecahkan masalah maka akan meningkatkan kemampuan siswa dalam memahami masalah, memikirkan penyusunan rencana dan menjalankannya untuk menghasilkan solusi yang benar sesuai konteks masalah yang diberikan. Kemampuan siswa memecahakan masalah matematika program linier ini kemudian dapat diperkuat atau ditingkatkan lagi dengan memberikan masalah matematika dalam bentuk open-ended problems (Nissa et al., 2019).

\section{SIMPULAN DAN SARAN}

Hasil uji hipotesis yang menunjukkan bahwa ada perbedaan kemampuan siswa yang memecahkan masalah program linier dalam bentuk soal cerita dan dalam bentuk grafik. Perbedaan ini disebabkan karena memahami masalah dalam bentuk soal cerita lebih sulit dibandingkan dengan masalah dalam bentuk grafik. Kegagalan siswa dalam mengingat kembali materi sebelumnya yang pernah dipelajari juga mempengaruhi kelancaran siswa dalam menyusun rencana pemecahan masalah. Selain itu, pengalaman siswa yang minim dalam menghadapi berbagai jenis soal matematika juga membuat siswa menjadi kurang kritis dalam menganalisa informasi penting dalam soal maupun memeriksa solusinya. Penelitian ini akan memberikan rujukan dalam hal pentingnya memberikan pengalaman pemecahan masalah matematika kepada siswa secara konsisten, berkelanjutan dan beragam dalam tingkat kesukarannya. Gagasan dari penelitian ini selanjutnya akan dikembangkan untuk merancang soal matematika yang tidak hanya memiliki multi jawaban tetapi juga multi strategi.

\section{UCAPAN TERIMA KASIH}

Ucapan terima kasih disampaikan kepada LPPM UNDIKMA dan SMA Islam Al-Azhar NW Kayangan Lombok Barat yang telah membantu penelitian ini dapat dilaksanakan.

\section{DAFTAR PUSTAKA}

Amaliah, A. I. (2018). Analisis Kesalahan Peserta Didik Dalam Menyelesaikan Soal Program Linier Pada Kelas XII IPA SMA Negeri 7 Mataram Semester Ganjil Tahun Ajaran 2017/2018. Unpublished Thesis. Mataram: Universitas Mataram.

Asih, I. . (2011). Peningkatan Kemampuan Siswa SMAN 8 Denpasar Dalam Menyelesaikan Soal Cerita Pokok Bahasan Program Linear Mata Pelajaran Matematika. Udayana Mengabdi, 10(2), 67-71.

Bazaraa, M. S., Jarvis, J. J., \& Sherali, H. D. (2011). Linear Programming and Network Flows ( Fourth Edition). Canada: John Wiley \& Sons, Inc. http://marefateadyan.nashriyat.ir/node/150

Hanifah, E. H. (2011). Identifikasi Kesalahan Siswa Dalam Menyelesaikan Soal Cerita Matematika materi Sistem Persamaan Linier Dua Variabel Berdasarkan Metode Analisis Kesalahan Newman : Studi Kasus SMP Bina Bangsa Surabaya.

Mahmudah, I. D., \& Sutarni, S. (2017). Kesalahan Siswa Dalam Menyelesaikan Soal 
Program Linier Bentuk Cerita Berbasis Newman di MAN Salatiga. Seminar Nasional Pendidikan Matematika, 1-8. Solo: Universitas Muhammadiyah Surakarta.

Mubarokah, I., \& Nusantara, T. (2020). Analisis Kesalahan Siswa Dalam Memodelkan Matematika Program Linear. Jurnal Pendidikan Matematika Undiksha, 11(2), 7988. https://ejournal.undiksha.ac.id/index.php/JJPM/article/view/24716

Mustaqim. (2013). Proses Scaffolding Berdasarkan Diagnosis Kesulitan Siswa dalam Menyelesaikan Masalah Program Linear dengan Menggunakan Mapping Mathematics. Jurnal Pendidikan Sains, 1(1), 72-78.

Ningrum, L. S. (2013). Analisis Kemampuan Siswa Menyelesaikan Soal Matematika Dalam bentuk Cerita Pokok Bahasan Barisan dan Deret Pada Siswa Kelas XII SMA AL-Islam 3 Surakarta.

Ninik, Hobri, \& Suharto. (2014). Analisis Kemampuan Pemecahan Masalah Untuk Setiap Tahap Model Polya Dari Siswa ASMK Ibu Pakusari Jurusan Multimedia Pada Pokok Bahasan Program Linier. Kadikma: Jurnal Matematika Dan Pendidikan Matematika, 5(3), 61-68. https://doi.org/10.12681/er.9602

Nissa, I. C., \& Lestari, P. (2015). Analisis Kemampuan Problem Solving Mahasiswa Calon Guru Matematika berdarkan Standar PISA. Jurnal Kependidikan, 14(1), 4556.

Nissa, I. C., Lestari, P., \& Kumala, D. (2019). Pengaruh pemberian soal Matematika Jenis Open-Ended Problems Terhadap Kemampuan Siswa Memecahkan Masalah Program Linier. Prisma Sains : Jurnal Pengkajian Ilmu Dan Pembelajaran Matematika Dan IPA IKIP Mataram, 7(2), 126-137. https://doi.org/10.33394/jps.v7i2.1910

Nurohmah, S. D., \& Setianingsih, R. (2014). Implementasi Scaffolding untuk Mengatasi Kesulitan Siswa Kelas X SMK Kartika 1 Surabaya dalam Meyelesaikan Soal Cerita pada Materi Program Linear. MATHEdunesa: Jurnal Ilmiah Pendidikan Matematika, 3(3), 221-229.

Rahmawati, D., \& Permata, L. D. (2018). Analisis Kesalahan Siswa dalam Menyelesaikan Soal Cerita Program Linear dengan Prosedur Newman. Jurnal Elektronik Pembelajaran Matematika, 5(2), 173-185.

Rosli, R., Goldsby, D., \& Capraro, M. M. (2013). Assessing Students' Mathematical Problem-Solving and Problem-Psing Skills. Asian Social Science, 9(16), 54-60. https://doi.org/10.5539/ass.v9n16p54

Schoenfeld, A. H. (2014). Expert and Novice Mathematical Problem Solving. Journal for Research in Mathematics Education, 13(1), 256-267.

Vanderbei, R. J. (2015). Linear Programming: Foundation and Extensions (Fourth Edition). 